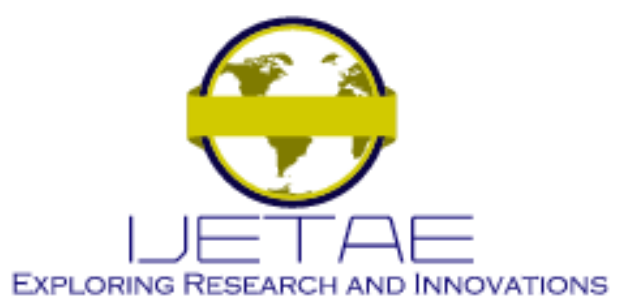

International Journal of Emerging Technology and Advanced Engineering

Website: www.ijetae.com (E-ISSN 2250-2459, Scopus Indexed, ISO 9001:2008 Certified Journal, Volume 11, Issue 07, July 2021)

Manuscript Received: 15 May 2021, Received in Revised form: 08 July 2021, Accepted: 14 July 2021 DOI: 10.46338/ijetae0721_07

\title{
Peculiarities of Implementing the State's Strategic Narrative based on the Public Opinion
}

\author{
Oleksandr Voitko ${ }^{1}$, Volodymyr Loza ${ }^{2}$, Hennadii Khudov $^{3}$, Valentyn Bakhvalov ${ }^{4}$, Igor Chernozubkin ${ }^{5}$, \\ Nina Kuchuk ${ }^{6}$, Oleksandr Oleksenko ${ }^{7},{\text { Maksym } \text { Chepel }^{8} \text {, Irina Khizhnyak }}^{9}$, Iryna Yuzova ${ }^{10}$ \\ ${ }^{1,2}$ National Defense University of Ukraine named after Ivan Cherniakhovskyi, Ukraine, Kyiv, 01001 \\ ${ }^{3,7,9,10}$ van Kozhedub Kharkiv National Air Force University, Ukraine, Kharkiv, 61023 \\ ${ }^{4}$ Military Institute of Taras Shevchenko National University of Kyiv, Ukraine, Kyiv, 03022 \\ ${ }^{5}$ Central Scientific Research Institute of the Armed Forces of Ukraine, Ukraine, Kyiv, 03049 \\ ${ }^{6}$ National Technical University "Kharkiv Polytechnic Institute", Ukraine, Kharkiv, 61002 \\ ${ }^{8}$ National Academy of the National Guard of Ukraine, Ukraine, Kharkiv, 61001
}

\begin{abstract}
The main purpose of the article is the peculiarities of implementing of the state's strategic narrative based on the the statistical analysis of the public opinion. The scenarios of the public opinion development are forecasted. The main results are: the graphs of the statistical series of change in public opinion have been constructed; the approximating functions for the trend of change in public opinion have been determined; the parameters of the approximating function have been calculated; a point forecast of the change in public opinion has been made. The main scientific method ia the method of statistical extrapolation. The main results are: to identify the features of the implementation of the strategic narrative of the state system in strategic communications; it is obtained the necessary minimum value of efficiency. This value of efficienct should be achieved by the system of strategic communications, when taking appropriate measures to promote and support of the appropriate course of the state by the population. This result is actually such as in the controlled territory and in the temporarily occupied territories (Donetsk and Luhansk regions, the Crimea).
\end{abstract}

Keywords - strategic narrative, target audience, informational and psychological influence, strategic communications.

\section{INTRODUCTION}

Joining NATO and European integration, that is Ukraine's civilizational choice, is one of the key demands of the Revolution of Dignity. From now on, this is enshrined in the Fundamental Law of Ukraine. The Verkhovna Rada approved amendments to the Constitution of Ukraine regarding the strategic course of the state for the acquisition of full membership in the European Union and the North Atlantic Treaty Organization [1].
Of course, this does not mean immediate accession to these international organizations, or even the beginning of a formalized process, but it should fundamentally change the atmosphere around this issue both in Ukraine and in the world.

Therefore, the authorities are obliged to bring Ukraine closer to the EU and NATO, to strengthen the economy, to build modern infrastructure, medicine, education, and a strong army according to NATO standards. It is now the constitutional duty of any government, of all its branches, regardless of the political spectrum, because it is the government that must build the path to the country's accession to the European Union and NATO. This is stated in the Fundamental Law of Ukraine.

\section{LITERATURE REVIEW AND PROBLEM STATEMENT}

In recent years, there have been many researches conducted by various international and Ukrainian foundations, centres and institutes on public opinion assessment [2-6]. However, there are no works that would define a strategic narrative or a state's task to achieve its goals in NATO-EU cooperation. Many materials are devoted to various public (population of Ukraine) opinion polls on European integration. However, comparative statistics and forecasting of changes in public opinion were not systematically conducted and were not used in setting the strategic goals of the state. As a result, no specific tasks were set for the strategic communications system of the Ministry of Defense and the Armed Forces of Ukraine.

In previous works [7, 8] the authors considered approaches to assessing the effectiveness of the strategic communications system of the Ministry of Defense and the Armed Forces of Ukraine and assessing threats to Ukraine's information security in the military sphere. 


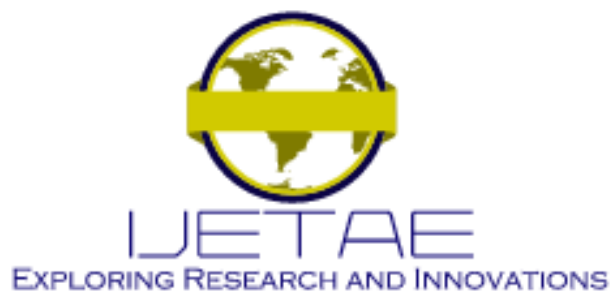

International Journal of Emerging Technology and Advanced Engineering

Website: www.ijetae.com (E-ISSN 2250-2459, Scopus Indexed, ISO 9001:2008 Certified Journal, Volume 11, Issue 07, July 2021)

It was also noted that the existing system of Strategic Communications is inefficient [7,8], all this is due to the lack of scientific approaches to determining the strategic narrative of the state.

The new version of the Military Doctrine of Ukraine defines the areas of military security and the task of acquiring the criteria necessary for membership in the European Union and the North Atlantic Treaty Organization [9].

In accordance with the Military Doctrine of Ukraine and the Strategic Defense Bulletin of Ukraine, on November 22, 2017 the Minister of Defense of Ukraine approved the Concept of Strategic Communications of the Ministry of Defense of Ukraine and the Armed Forces of Ukraine №612 [10, 11]. This document states that the use of all communicative capabilities of the state is aimed at achieving its goals.

Strategic communications today are in the process of formation, and this process, in contrast to the world's leading countries, takes place in real combat conditions. Therefore, the existing problems and difficulties need to be promptly identified and resolved. The basis for building strategic communications includes the formation of a strategic narrative.

The aim of the article is to scientifically substantiate the peculiarities of the implementing of the state's strategic narrative on the basis of the analysis of statistical data of public opinion and forecasting of scenarios of its development.

To accomplish the aim, the following tasks have been set:

to forecast the desired general trends of public opinion on the accession to the EU, NATO and on the non-aligned status of Ukraine in 2021 and 2022;

to determine the point values of forecast data of public opinion polls for 2021-2022 on accession to the EU, NATO and on the non-aligned status of Ukraine; to calculate the projected data on the growth (decrease) of the quantitative assessment of the distribution of public opinion on the accession to the EU, NATO and on the nonaligned status of Ukraine in 2021 and 2022.

\section{MATERIALS AND RESEARCH METHODS}

The sixth year of the war with the aggressor in Donbass and the temporarily occupied territories gave our state a "bloody lesson" from which we've learned the price of independence and territorial integrity. Every day our state gains more and more new capabilities in the fight against the Russian Federation. Of particular relevance and importance in modern conditions is the study of informational and psychological impact on the population of the temporarily occupied territories made by the enemy and the construction of a scientifically sound effective system of information security of Ukraine in the military sphere in the form of strategic communications of the Ministry of Defense and Armed Forces.

As noted, the Ukrainian legislation involves a strategic course of the state to gain full membership of Ukraine in the EU and NATO.

Since independence was gained, disputes over the definition and arrangement of the social and political worldview, national self-determination, have arisen in Ukrainian society.

Public opinion polls in Ukraine were not conducted systematically and their data were not generalized. They were carried out only to determine the level of support for various political parties that came or were in power. Therefore, in order to conduct a systematic and scientifically sound analysis, the authors have collected all available statistics to determine changes in public opinion regarding the strategic course of the state since 2002 , depending on the military-political, economic and social living conditions of the population of Ukraine at the specified period of time [12-17]. These data are shown in Table 1. 


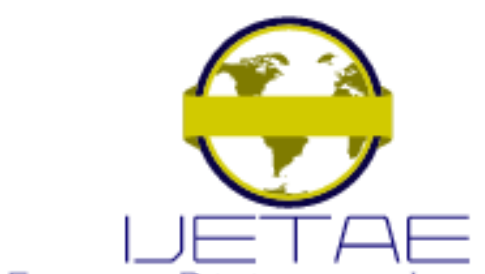

EXPLORING RESEARCH AND INNOVATIONS

International Journal of Emerging Technology and Advanced Engineering

Website: www.ijetae.com (E-ISSN 2250-2459, Scopus Indexed, ISO 9001:2008 Certified Journal, Volume 11, Issue 07, July 2021)

TABLE I

Aggregated Statistics ON the ACCession to the EU, NATO AND ON THE NON-ALigned Status

\begin{tabular}{|c|c|c|c|c|c|c|c|c|c|c|c|}
\hline \multirow[b]{2}{*}{ Year } & \multirow[b]{2}{*}{ Population } & \multicolumn{4}{|c|}{ Accession to the EU } & \multicolumn{4}{|c|}{ Accession to the NATO } & \multicolumn{2}{|c|}{ Non-aligned status } \\
\hline & & For $\%$ & $\begin{array}{c}\text { Number of } \\
\text { people }\end{array}$ & $\begin{array}{c}\text { Agains } \\
\text { t } \%\end{array}$ & $\begin{array}{l}\text { Number } \\
\text { of people }\end{array}$ & For $\%$ & $\begin{array}{l}\text { Number of } \\
\text { people }\end{array}$ & $\begin{array}{c}\text { Against } \\
\%\end{array}$ & $\begin{array}{l}\text { Number } \\
\text { of people }\end{array}$ & $\%$ & $\begin{array}{c}\text { Number of } \\
\text { people }\end{array}$ \\
\hline 2002 & 48457,1 & 61,35 & 29728,4 & 14,55 & 7050,5 & - & - & - & - & - & - \\
\hline 2003 & 48003,5 & 61,55 & 29546,2 & 15,88 & 7623,0 & - & - & - & - & - & - \\
\hline 2004 & 47622,4 & 52,2 & 24858,9 & 23,6 & 11238,9 & - & - & - & - & - & - \\
\hline 2005 & 47280,8 & 45,9 & 21701,9 & 32,5 & 15366,3 & - & - & - & - & - & - \\
\hline 2006 & 46929,5 & 48,5 & 22760,8 & 32 & 15017,4 & - & - & - & - & - & - \\
\hline 2007 & 46646,0 & 51,4 & 23976,0 & 30,7 & 14320,3 & 18,9 & 8816,1 & 31,3 & 14600,2 & 30,7 & 14320,3 \\
\hline 2008 & 46372,7 & 50,9 & 23603,7 & 29,2 & 13540,8 & - & - & - & - & - & - \\
\hline 2009 & 46143,7 & 44,4 & 20487,8 & 38,3 & 17673,0 & 18 & 8305,9 & 30 & 13843,1 & - & - \\
\hline 2010 & 45962,9 & 52,8 & 24268,4 & 24,2 & 11123,0 & 18 & 8273,3 & 29 & 13329,2 & - & - \\
\hline 2011 & 45778,5 & 51,2 & 23438,6 & 30,3 & 13870,9 & 18 & 8240,1 & 27 & 12360,2 & - & - \\
\hline 2012 & 45633,6 & 46,1 & 21037,1 & 32,9 & 15013,5 & 13 & 5932,4 & 26,2 & 11956,0 & 42,1 & 19211,7 \\
\hline 2013 & 45553,0 & 49,2 & 22412,1 & 34,4 & 15670,2 & 19 & 8655,1 & 21 & 9566,1 & - & - \\
\hline 2014 & 45426,2 & 57 & 25892,9 & 28,6 & 12991,9 & 40,7 & 18488,5 & 12,6 & 5723,7 & 23,8 & 10811,4 \\
\hline 2015 & 42929,3 & 52,7 & 22623,7 & 29,1 & 12492,4 & 45,7 & 19618,7 & 8,2 & 3520,2 & 22,6 & 9702,0 \\
\hline 2016 & 42760,5 & 54,1 & 23133,4 & 30,9 & 13213,0 & 44,1 & 18857,4 & 6,4 & 2736,7 & 26,4 & 11288,8 \\
\hline 2017 & 42584,5 & 56,5 & 24060,2 & 26,8 & 11412,6 & 38,5 & 16395,0 & 5,3 & 2257,0 & 28,6 & 12179,2 \\
\hline 2018 & 42386,4 & 52 & 22040,9 & - & - & 46,1 & 19540,1 & 7,2 & 3051,8 & 24,1 & 10215,1 \\
\hline 2019 & 42153,2 & 52 & 21919,7 & 25 & 10538,3 & 40,9 & 17240,7 & 7,4 & 3119,3 & 35,9 & 15133,0 \\
\hline 2020 & 41588,4 & 51,9 & 21584.4 & 25,8 & 10729,8 & 41,3 & 17176,0 & 7,1 & 2952,8 & 36,4 & 15138,2 \\
\hline
\end{tabular}

In $201846 \%$ of the population thought that Ukraine's accession to NATO was the best way to guarantee Ukraine's national security. Public support for Alliance membership began to grow rapidly in 2014 and it has become a trend. Thus, if in 2012 only $13 \%$ of Ukrainians relied on NATO as a source of security, then in May 2014 their number increased up to 33\%, in December 2014 $44 \%$ and in November 2015 - 46\%.

At the same time, the idea of non-alignment and a military alliance with Russia and other CIS countries has lost its appeal. In particular, in 2012, non-aligned status was the leader in terms of support by society: $42 \%$ of the population considered it as a guarantee of national security. After the annexation of Crimea and the start of the war in Donbas, the share of supporters of non-alignment fell sharply to $28 \%$ in May 2014 and to $23 \%$ in November 2015. Support for a military alliance with Russia and other CIS countries fell sharply after the annexation of Crimea and Russia's aggressive actions in Donbass. Thus in April 2012 the alliance with Russia was considered a source of security by $26 \%$ of Ukrainians, then in May 2014 - 13\%, and in November 2015 only $8 \%$ of population supported this option [11].
If we consider the issue of European integration, during the pre-war years (2011-2013) the share of supporters of EU accession accounted about a third of respondents, and with the beginning of Russian aggression the share of sympathizers of the Eurasian Economic Union (former CIS Customs Union) fell to $15.9 \%$ in 2015, and decreased to $7.8 \%$ in 2017. Accordingly, the share of supporters of the European integration has increased.

Since 2014 there has been a growing trend of European sympathy in society. In December 2017 almost 60\% of Ukrainian citizens supported Ukraine's accession to the EU [11].

Public opinion about European and North Atlantic cooperation has gained very drastic changes with the beginning of the armed aggression of the Russian Federation. During the war, Ukrainian society did not get the desired result in terms of proper support and maintainance of national security of Ukraine from the EU and NATO. Therefore, starting from 2017, the number of supporters of such integration began to decrease gradually. It is clear from the above that public opinion on joining the EU and NATO has changed depending on the political, military and economic processes that have taken place in Ukraine over the past two decades. 


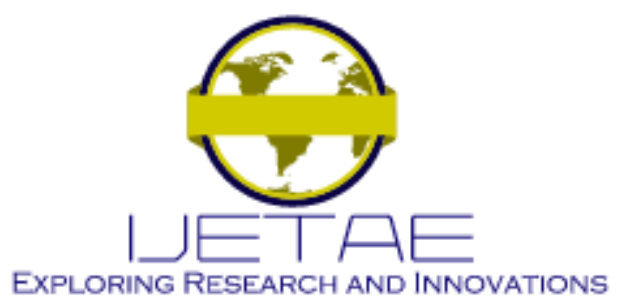

International Journal of Emerging Technology and Advanced Engineering

Website: www.ijetae.com (E-ISSN 2250-2459, Scopus Indexed, ISO 9001:2008 Certified Journal, Volume 11, Issue 07, July 2021)

All this is confirmed by the results of the analysis of statistical data. But to achieve the stated aim of the study, it is not enough to assess only the current distribution of public opinion on these issues. It is necessary to identify general trends in its (public opinion) change for each issue in the future; choose the ones that are directed in the desired direction for us and are characterized by the greatest reliability. This can be achieved using scientific forecasting, namely the method of statistical extrapolation. The peculiarity of scientific forecasting is that it is aimed at the future, and its main task is to identify trends, the logic of the process that is projected. This reduces the uncertainty of the future situation on the results of decisions made.

The method of statistical extrapolation is to define on the basis of reliable statistics about the predicted object (process), its determined (non-random) basis (trend) and calculate its values for a given future point of time, as well as to estimate the range of possible dispersion relative to the average value.

The solution of the problem of extrapolation forecasting can be carried out in the following sequence: a) to plot a statistical series of changes in public opinion; b) to choose the approximating function for the trend of the process under study; c) to calculate the parameters of the approximating function; d) to obtain a point forecast and its reliability.

The initial information is presented in the form of a statistical series of $n$ values of the function $y(t)$ given in Table 1.

The use of extrapolation in forecasting is based on the assumption that the process under study can be represented by a combination of two components: regular and random (Fig. 1):

$$
Y(t)=f(\bar{a}, t)+\eta(t)
$$

Regular component - the trend $f(\bar{a}, t)$ is a smooth function of the argument $t$ and parameter $\bar{a}\left(a_{1}, a_{2}, \ldots, a_{m}\right)$, which takes its value for the period ahead of the forecast. Random component $\eta(t)$ is considered a non-relatable random process with zero mathematical expectation.

Extrapolation methods of forcasting is to identify a trend and extrapolate its values over the bias interval. The value of the trend at the given extrapolation point is similar to the point forecast.
When choosing a function, which approximates the trend of the process under study, the logic of the process should be studied, including the predictions about its development in the future.

As a trend, depending on the characteristics of the statistical manifestations of the behavior of the function $\mathrm{y}(\mathrm{t})$ under study, the following is most often chosen: linear, power, exponential, logarithmic or polynomial function [18-20].

When calculating trend parameters, it is necessary, using research data, to calculate the values of these parameters that will provide an optimal approximation. The criterion of optimality is a degree of deviation of the points of the research series from the approximating function.

We will use the least squares method as an optimality criterion. The method is based on minimizing the algebraic sum of squares of deviations of research points from the approximating curve [21-23]:

$$
\mathrm{S}=\sum_{\mathrm{i}=1}^{\mathrm{n}}\left[\mathrm{y}_{\mathrm{i}}-\mathrm{f}\left(\mathrm{t}_{\mathrm{i}}, \mathrm{a}_{1}, \mathrm{a}_{2}, \ldots, \mathrm{a}_{\mathrm{m}}\right)\right]^{2} \rightarrow \min ,
$$

where $y_{i}, t_{i}$ is the ordinate and abscissa of the $\mathrm{i}$-th point of the series;

$$
\mathrm{a}_{1}, \mathrm{a}_{2}, \ldots, \mathrm{a}_{\mathrm{m}}-\text { unknown parameters of the }
$$
approximating curve.

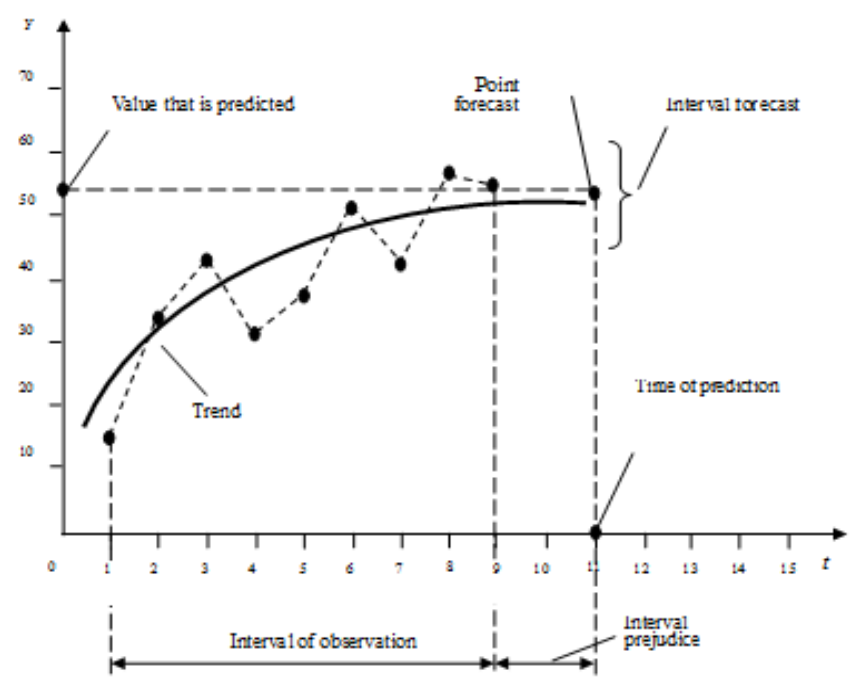

Fig 1. Graphical interpretation of the extrapolation method of forecasting 


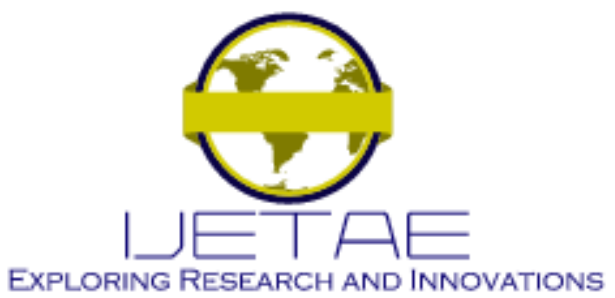

International Journal of Emerging Technology and Advanced Engineering Website: www.ijetae.com (E-ISSN 2250-2459, Scopus Indexed, ISO 9001:2008 Certified Journal, Volume 11, Issue 07, July 2021)

A. Results of Public Opinion Polls on EU Accession, NATO and Ukraine's Non-aligned Status

The method is prectically implemented to determine the parameters $\mathrm{a}_{1}, \mathrm{a}_{2}, \ldots, \mathrm{a}_{\mathrm{m}}$ when solving system of equation: $\frac{\mathrm{ds}}{\mathrm{da}_{1}}=0, \frac{\mathrm{ds}}{\mathrm{da}_{2}}=0, \ldots, \frac{\mathrm{ds}}{\mathrm{da}_{\mathrm{m}}}=0$.

An approximate function, that describes a trend or a regular component of the process, is mathematical expectation of this rendom process on an observation interval [24-26].

To obtain the point forecast, the function extrapolates on the advance interval. The value of the function in the end of interval if $\mathrm{t}=\mathrm{t}_{\mathrm{pr}}$ conforms with a point forecast: $\tilde{y}\left(t_{p r}\right)=f\left(t_{p r}, a_{1}, a_{2}, \ldots, a_{m}\right)$.

To determine the interval forecast, it is necessary to know the characteristics of the accuracy and reliability of the forecast. If $\mathrm{M}[\eta]=0$ the estimation of variance is determined by the formula of mathematical statistics: $\tilde{D}[\eta]=\frac{1}{n-1} \sum_{i=1}^{n}\left[y_{i}\left(t_{i}\right)-\tilde{y}\left(t_{i}\right)\right]^{2}$.

The accuracy of the forecast is determined by the standard deviation $\tilde{\varepsilon}_{\text {пр }}=\sqrt{\frac{\tilde{\mathrm{D}}(\eta)}{\mathrm{n}}}$.

The interval forecast is determined by the formula $\mathrm{P}\left[\tilde{\mathrm{y}}\left(\mathrm{t}_{\mathrm{pr}}\right)-\mathrm{t}_{\beta} \tilde{\varepsilon}_{\mathrm{pr}} \leq \mathrm{y}_{\mathrm{pr}} \leq \tilde{\mathrm{y}}\left(\mathrm{t}_{\mathrm{pr}}\right)+\mathrm{t}_{\beta} \tilde{\varepsilon}_{\mathrm{pr}}\right]=\beta$, where $\beta$ is the confidence probability, $\left(\tilde{y}\left(t_{p r}\right)-t_{\beta} \tilde{\varepsilon}_{\mathrm{pr}}, \tilde{y}\left(t_{\mathrm{pr}}\right)+t_{\beta} \tilde{\varepsilon}_{\mathrm{pr}}\right)$, the confidence interval of the forecast.

With a small number of observations in the initial statistical series, $t_{\square}$ is determined by the Student's $t$ distribution. With a sufficiently large number of observations, $t$ is determined by the normal distribution law.

The reliability of the approximation is determined by the coefficient of determination: $\mathrm{R}^{2}=1-\varphi^{2}$, the closer this coefficient is to unity, the more accurate the model is.

$$
\varphi^{2}=\frac{\sum_{i=1}^{n}\left(y_{i}-\tilde{y}_{i}\right)^{2}}{\sum_{i=1}^{n}\left(y_{i}-\bar{y}_{i}\right)^{2}}-\text { is a convergence factor, where } \bar{y}_{i}
$$

is the arithmetic mean of the sample.

In order to reduce the time of calculations and increase their accuracy, all mathematical procedures will be carried out using the software product Microsoft Office Excel.

The process of forecasting public opinion on EU accession, NATO and Ukraine's non-aligned status will be carried out in turn following the above stages.

1. Forecasting public opinion on Ukraine's accession to the EU for 2021-2022:

a) plotting a statistical series of changes in public opinion on EU accession for the period from 2002 to 2020.

The process of plotting (Fig. 2) was implemented using the software product Microsoft Office Excel based on the statistics of table 2 . 


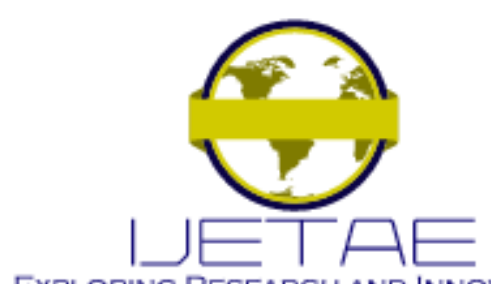

EXPLORING RESEARCH AND INNOVATIONS

International Journal of Emerging Technology and Advanced Engineering

Website: www.ijetae.com (E-ISSN 2250-2459, Scopus Indexed, ISO 9001:2008 Certified Journal, Volume 11, Issue 07, July 2021)

TABLE II

Statistics on Public OPINION ON EU ACCESSion

\begin{tabular}{|c|c|c|c|c|c|c|c|c|c|c|c|c|c|c|c|c|c|c|c|c|c|c|c|}
\hline $\begin{array}{l}\text { Number of } \\
\text { respondents }\end{array}$ & \multicolumn{19}{|c|}{ Observation interval (Years) } & \multicolumn{2}{|c|}{ Forecast } & \multicolumn{2}{|c|}{ Increase } \\
\hline "for" & 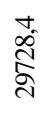 & 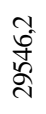 & 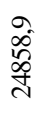 & $\frac{\vec{\rho}}{\frac{a}{N}}$ & 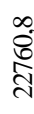 & $\begin{array}{l}\text { ठे } \\
\text { ळे } \\
\text { ते }\end{array}$ & $\begin{array}{l}\hat{\tilde{\delta}} \\
\text { did } \\
\end{array}$ & $\begin{array}{l}\text { - } \\
\text { } \\
\stackrel{\infty}{+}\end{array}$ & 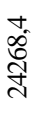 & 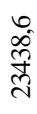 & $\begin{array}{l}\overrightarrow{\widehat{\sigma}} \\
\stackrel{0}{\sigma}\end{array}$ & $\begin{array}{l}\overrightarrow{\mathrm{d}} \\
\stackrel{\mathbb{d}}{\mathrm{d}}\end{array}$ & 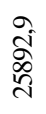 & $\begin{array}{l}\text { तె } \\
\text { तై }\end{array}$ & $\frac{\vec{m}}{\stackrel{d}{\sigma}}$ & 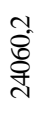 & $\begin{array}{l}\text { के } \\
\text { ते }\end{array}$ & $\begin{array}{l}\hat{\sigma} \\
\vec{\sigma}\end{array}$ & $\begin{array}{l}\stackrel{+}{+} \\
\stackrel{\sim}{\stackrel{D}{N}}\end{array}$ & $\begin{array}{l}0 \\
\text { ஸे } \\
\tilde{N} \\
\text { ते }\end{array}$ & 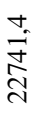 & 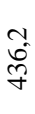 & $\stackrel{0}{\stackrel{0}{+}}$ \\
\hline$\%$ & $\frac{n}{6}$ & $\frac{n}{6}$ & กี & चे & $\stackrel{n}{\infty}$ & $\dot{n}$ & $\hat{\text { हे }}$ & $\stackrel{+}{+}$ & $\begin{array}{l}\infty \\
i \\
\text { in }\end{array}$ & $\frac{1}{n}$ & की & $\tilde{q}$ & $i n$ & $\hat{\text { กิ }}$ & $\overrightarrow{i n}$ & ñ & กิ & $\approx$ & $\frac{a}{n}$ & ते & $\begin{array}{l}0 \\
\dot{1}\end{array}$ & $\stackrel{0}{=}$ & $\hat{i}$ \\
\hline "against" & $\begin{array}{l}n \\
2 \\
2 \\
2\end{array}$ & तु & $\begin{array}{l}\text { के } \\
\stackrel{ٍ}{\Xi} \\
\vec{\Xi}\end{array}$ & 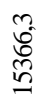 & 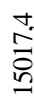 & 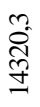 & $\begin{array}{l}\infty \\
\stackrel{0}{0} \\
\text { mn }\end{array}$ & 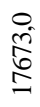 & $\begin{array}{l}\stackrel{\circ}{\Xi} \\
\underset{\Xi}{\Xi}\end{array}$ & $\begin{array}{l}\hat{c} \\
\stackrel{\infty}{=} \\
\stackrel{=}{2}\end{array}$ & $\begin{array}{l}\stackrel{n}{m} \\
\stackrel{\circ}{2}\end{array}$ & 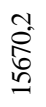 & $\frac{\overrightarrow{\mathrm{d}}}{\overrightarrow{\mathrm{d}}}$ & $\begin{array}{l}\stackrel{+}{\sigma} \\
\stackrel{d}{d}\end{array}$ & $\begin{array}{l}\stackrel{0}{\pi} \\
\stackrel{\sim}{2}\end{array}$ & $\begin{array}{l}0 \\
\mathfrak{d} \\
\Xi \\
\Xi\end{array}$ & ' & $\begin{array}{l}\text { ?. } \\
\infty \\
\tilde{ల} \\
\tilde{0}\end{array}$ & 交 & $\begin{array}{l}\text { r. } \\
\text { ñ } \\
\hat{0}\end{array}$ & $\begin{array}{l}\vec{m} \\
\infty \\
\alpha\end{array}$ & ָิ & $\begin{array}{l}\text { ชู } \\
\frac{1}{1}\end{array}$ \\
\hline
\end{tabular}

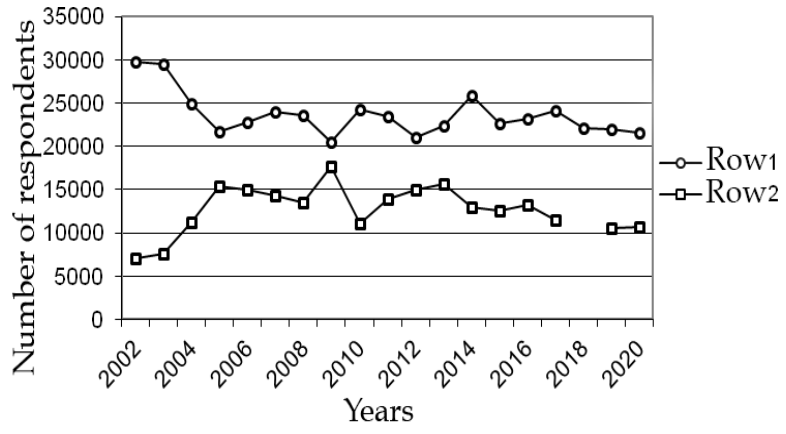

Fig. 2. Statistics of public opinion data on Ukraine's accession to the EU

In the obtained graph, line 1 shows the tendencies of the public opinion for supporting state's direction to access the EU. Line 2 shows the tendency of the public opinion against this direction.

b) the choice of the trend (approximating function), based on the desired prospects for the development of the process under study, and the reliability of the selected approximation of the studied function.

This procedure was also performed using the Microsoft Office Excel software product sequentially for several possible trend options.
In our case, in the study, three functions were considered as approximating trend functions: power, exponential, and second-order polynomial function (Fig. 3-5).

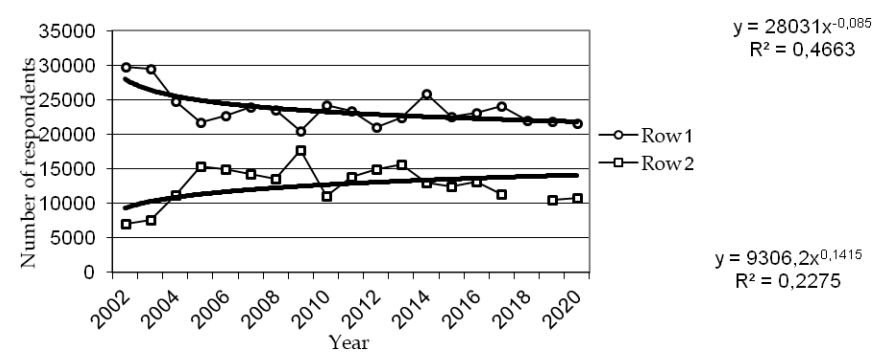

Fig. 3. Approximation of the trend by the power function

When calculating the trend parameters by the power function, the trend equation of line 1 will be $y=27993 x^{-0,084}$, and the reliability of the approximation $\mathrm{R}^{2}=0,4432$, respectively the trend equation of line 2 will be $\mathrm{y}=8984,4 \mathrm{x}^{0,1675}$, the reliability of the approximation $\mathrm{R}^{2}=0,3002$. Such values of the reliability of the approximation are unacceptably low, in addition, the chosen trend indicates a decrease in support of state's course to join the EU and increase of number of its opponents, so it is necessary to abandon the approximation of the studied process by the power function. 


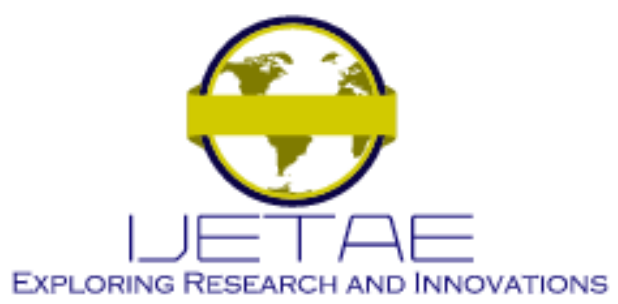

International Journal of Emerging Technology and Advanced Engineering

Website: www.ijetae.com (E-ISSN 2250-2459, Scopus Indexed, ISO 9001:2008 Certified Journal, Volume 11, Issue 07, July 2021)

Let's consider the approximation of trends in public opinion regarding EU accession using the exponential function (Fig. 4).

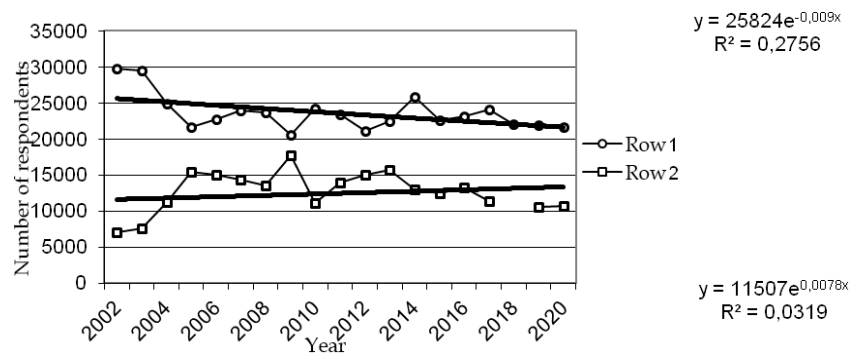

Fig. 4. Approximation of a trend by an exponential function

When calculating the trend parameters by the exponential function, the trend equation of line 1 will be $\mathrm{y}=25819 \mathrm{e}^{-0,009 \mathrm{x}}$, the reliability of the approximation $\mathrm{R}^{2}=0,2431$, the trend equation of line 2 will be $\mathrm{y}=11131 \mathrm{e}^{0,0129 \mathrm{x}}$, the reliability of the approximation $\mathrm{R}^{2}=0,0731$. Such a low reliability of the approximation is also unacceptable, so we will consider the approximation of the process of changing public opinion on joining the EU using a polynomial function of the second order (Fig. 5).

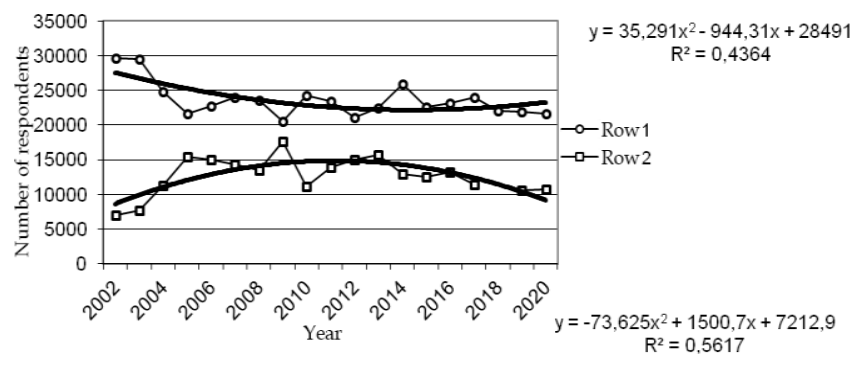

Fig. 5. Approximation of a trend by a polynomial function of the second order

When calculating the trend parameters using a polynomial function of the second order, the trend equation of line 1 will be $y=45,734 x^{2}-1109,3 x+28930$, the reliability of the approximation $R^{2}=0,4569$, respectively, the trend equation of line 2 will be $y=-85,618 x^{2}+1685 x+6734,3$, and the reliability of the approximation $\mathrm{R}^{2}=0,5836$.
Comparative analysis of the patterns of behavior of the lines of selected trends depending on the time shown in Fig. 3-5 convinces of the expediency of choosing as an approximating function is a polynomial function of the second order.

As we can see, the trends of prospects for the changes in public opinion regarding the accession to the EU while approximating the process of change by power and exponential functions do not correspond to the provisions of the Constitution of Ukraine. The trend for joining the EU is declining, and the trend against accession is growing. In addition, the reliability of the forecast using such trends is extremely low. When approximating a trend by a power function $R^{2}=0,4432$ for the trend of public opinion for EU accession and $R^{2}=0,3002$ for the trend against EU accession. Similarly, when the trend is approximated by an exponential function, the reliability of the approximation is $R^{2}=0,2431$ and $R^{2}=0,0734$ respectively. When we apply the second-order polynomial function as an approximating function of the development process, the trends in the development of changes in public opinion regarding EU accession are satisfactory and the reliability of the approximation is quite high $\left(R^{2}=0,4569\right.$ and $\mathrm{R}^{2}=0,5836$ ). Therefore, we choose a second-order polynomial function as an approximating function of the studied process.

\section{c) calculation of parameters of the approximating function (trend);}

Using the software product Microsoft Office Excel, the calculation process is done simultaneously with the construction of the selected trend on the graph of the statistical line of the process, as well as the equations of approximating functions are given.

\section{d) obtaining a point forecast and its reliability.}

If we have the trend equation, the process of calculating of its value at the forecast point can be obtained analytically by substituting the corresponding value $x$ in the trend equation. But when using the Microsoft Office Excel software, this happens automatically and the corresponding point forecast marks appear on the trend chart, and their numerical values for 2021 and 2022 are recorded in the table of statistical data of the studied process (Fig. 6, Table 2). 


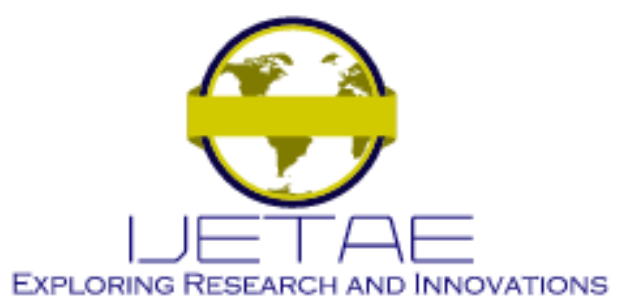

International Journal of Emerging Technology and Advanced Engineering

Website: www.ijetae.com (E-ISSN 2250-2459, Scopus Indexed, ISO 9001:2008 Certified Journal, Volume 11, Issue 07, July 2021)

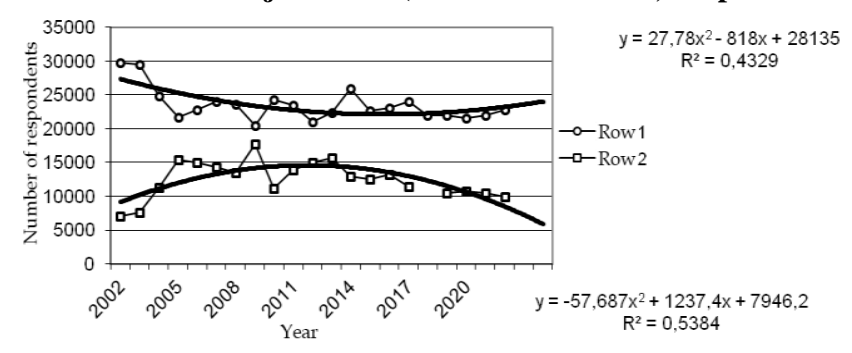

Fig. 6. Forecast of public opinion on accession to the EU for 2021-2022 when the trend is approximated by a polynomial function of the second order

The reliability of the point forecast for line 1 is characterized by the value $R^{2}=0,4661$, and $\mathrm{R}^{2}=0,7217$ for line 2 , respectively. The obtained numerical values of the point forecast of public opinion of the population on accession to the EU for 2021 and 2022 are shown in Table 2.
The difference between the indicators of the forecast and the indicators of these values in 2020 is reflected in the table in the column "growth" and indicates the required minimum value of efficiency, which should be achieved by a system of strategic communications while carrying out appropriate activities to promote and support the corresponding European course of the state by the population.

2. Forcasting public opinion regarding NATO membership for 2021-2022:

a) the construction of a graph of a statistical series of changes in public opinion regarding joining NATO in the period from 2007 to 2020 is carried out on the basis of the data in Table 3 using the Microsoft Office Excel software product (Fig. 7).

TABLE III

Public Opinion Statistics ON NATO ACCESSION

\begin{tabular}{|c|c|c|c|c|c|c|c|c|c|c|c|c|c|c|c|c|c|c|c|c|c|c|c|}
\hline \multirow{2}{*}{$\begin{array}{l}\text { Number of } \\
\text { respondents }\end{array}$} & \multicolumn{19}{|c|}{ Observation interval (Years) } & \multicolumn{2}{|c|}{ Forecast } & \multicolumn{2}{|c|}{ Growth } \\
\hline & రิ & ڤ్రి & ¿্ণ & ڤి & ¿্ণ & $\widehat{్}$ & $\stackrel{i}{0}_{0}^{\infty}$ & ڤ્ণ & 윰 & $\bar{\Xi}$ & $\stackrel{4}{\stackrel{4}{2}}$ & $\stackrel{m}{\stackrel{n}{i}}$ & $\stackrel{\text { d }}{\overrightarrow{4}}$ & $\stackrel{n}{2}$ & $\stackrel{\circ}{\circ}$ & 혹 & $\stackrel{\infty}{\stackrel{i}{*}}$ & ᄅे & ठั่ & $\overrightarrow{\widetilde{d}}$ & ธิ & $\overrightarrow{\widetilde{d}}$ & ธิ \\
\hline$\%$ & ' & ' & ' & ' & ' & $\stackrel{0}{\infty}$ & ' & $\stackrel{\infty}{\sim}$ & $\stackrel{\infty}{-}$ & $\infty$ & $\stackrel{2}{2}$ & 9 & $\hat{q}$ & $\hat{y}$ & $\vec{f}$ & $\begin{array}{l}n \\
\infty \\
n\end{array}$ & $\vec{b}$ & $\hat{\dot{q}}$ & $\frac{m}{7}$ & $\begin{array}{l}\infty \\
\dot{f}\end{array}$ & 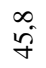 & $n$ & 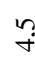 \\
\hline$\%$ & ' & ' & ' & ' & ' & $\frac{m}{m}$ & ' & @ & ते & $\widehat{\imath}$ & ป̂ & $\bar{\sim}$ & $\begin{array}{l}0 \\
\mathrm{I}\end{array}$ & No & $t_{0}^{+}$ & ?n & $\stackrel{N}{\sim}$ & $\underset{r}{\stackrel{\Delta}{*}}$ & $\vec{\sigma}$ & $\stackrel{0}{0}$ & $\stackrel{0}{0}$ & $\because$ & $\stackrel{\circ}{\circ}$ \\
\hline
\end{tabular}

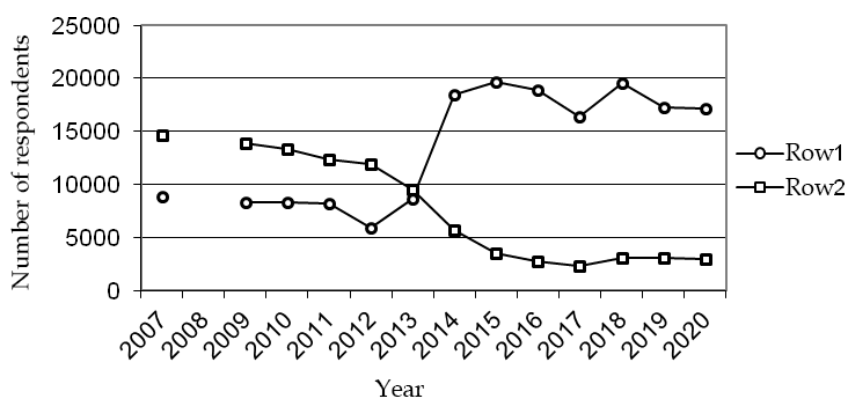

Fig. 7. Statistics of public opinion data on Ukraine's accession to NATO
In the obtained graph, line 1 shows trends in public opinion in support of the state's course towards NATO membership. Respectively line 2 shows tendencies of change of public opinion against this course. According to the statistics, there is a trend to the decrease in the number of population, who support the external political course of our state to join NATO. Therefore, for the system of strategic communications, it is advisable to set the task of popularizing the appropriate course of the state among the population and determine the corresponding indicators that must be achieved while implementing these tasks. 


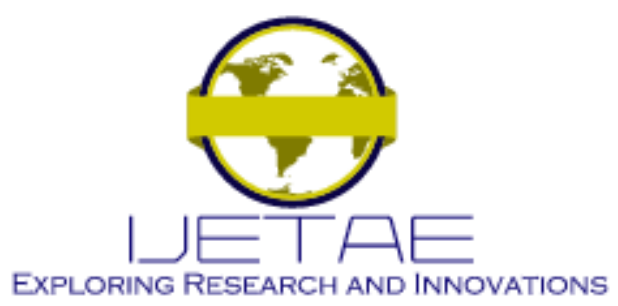

International Journal of Emerging Technology and Advanced Engineering

Website: www.ijetae.com (E-ISSN 2250-2459, Scopus Indexed, ISO 9001:2008 Certified Journal, Volume 11, Issue 07, July 2021)

$b$, c) selection of the approximating function and calculation of trend parameters.

This process is also carried out using the software product Microsoft Office Excel, taking into account the desired prospects for the development of the process under study, and the reliability of the approximation.

The following were considered as approximating functions: linear, power and polynomial functions.

The analysis of the obtained graphs according to the previous scheme showed the expediency of choosing a second-order polynomial function as an approximating function of the studied process. The development of the process over time occurs in this case in the desired strategic direction and the reliability of the approximation of the studied process is quite high (Fig. 8).

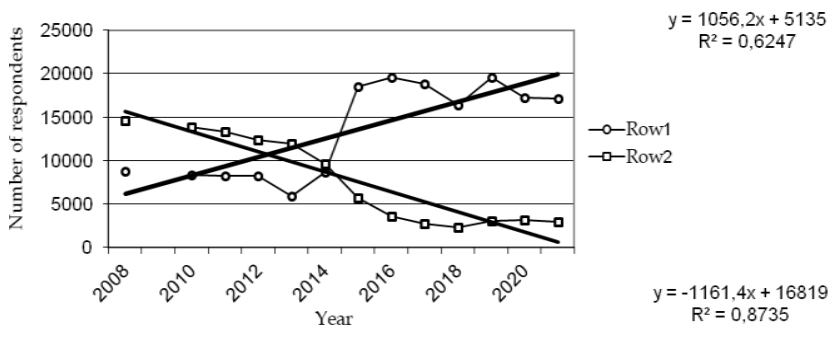

Fig. 8. Approximation of a trend by a polynomial function of the second order

Indeed, when calculating the trend parameters by a second-order polynomial function, the trend equation of line 1 will be $y=32,468 x^{2}-705,77 x+5757,4$ and the reliability of the approximation $\mathrm{R}^{2}=0,6449$. For line 2 of the trend equation will be $\mathrm{y}=8,6723 \mathrm{x}^{2}-1387,9 \mathrm{x}+17710$, the reliability of the approximation $-\mathrm{R}^{2}=0,8914$. These values exceed the corresponding figures of the reliability of the approximation of the studied process when the power and linear functions are used as a trend.

d) making of the point forecast and the assessment of its reliability also were carried out using the Microsoft Office Excel software product. The results of this process are shown in Fig. 9. The reliability of the point forecast for line 1 is characterized by the value $\mathrm{R}^{2}=0,8382$, respectively for line $2: \mathrm{R}^{2}=0,8453$.

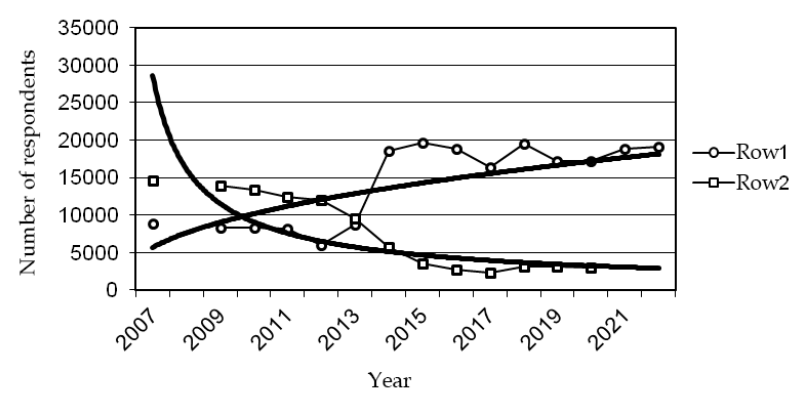

Fig. 9. Forecast of public opinion on NATO accession for 2021-2022 with the approximation of the trend by a polynomial function of the second order

The obtained numerical values of the point forecast of public opinion on NATO accession for 2021 and 2022 are shown in Table 3 . This table also shows the increase in the required indicators for 2021-2022.

3. Forecasting public opinion on the non-aligned status of Ukraine for 2021-2022.

a) plotting a statistical series of changes in public opinion on the non-aligned status of Ukraine in the period from 2007 to 2020.

This operation was implemented (Fig. 10) using the software product Microsoft Office Excel using the statistics shown in Table 4.

TABLE IV

PUblic Opinion Statistics ON NON-ALigned Status

\begin{tabular}{|c|c|c|c|c|c|c|c|c|c|c|c|c|c|c|c|}
\hline \multirow{2}{*}{$\begin{array}{l}\text { Number of } \\
\text { respondents }\end{array}$} & \multicolumn{11}{|c|}{ Observation interval (Years) } & \multicolumn{2}{|c|}{ Forcast } & \multicolumn{2}{|c|}{ Growth } \\
\hline & ఠิ & ڤ્ণ & ¿্ণ & ڤ્ণ & ๕્ત & ڤ્ণ & 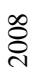 & ڤ્ণ & $\stackrel{\circ}{\stackrel{i}{~}}$ & $\bar{c}$ & & $\overline{\widetilde{\Lambda}}$ & ָิ & $\overrightarrow{\widetilde{d}}$ & ฮิ \\
\hline "for" & ' & ' & ' & ' & ' & $\begin{array}{l}\stackrel{m}{0} \\
\stackrel{N}{N} \\
\stackrel{\Xi}{ \pm}\end{array}$ & ' & ' & & & & 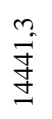 & 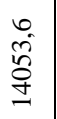 & $\frac{\infty}{\tilde{m}_{0}^{+}}$ & $\frac{n}{8}$ \\
\hline$\%$ & , & ' & ' & ' & ' & $\hat{0}$ & ' & ' & ' & & & זे & $\stackrel{\infty}{m}$ & 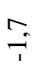 & $\begin{array}{l}0 \\
i\end{array}$ \\
\hline
\end{tabular}




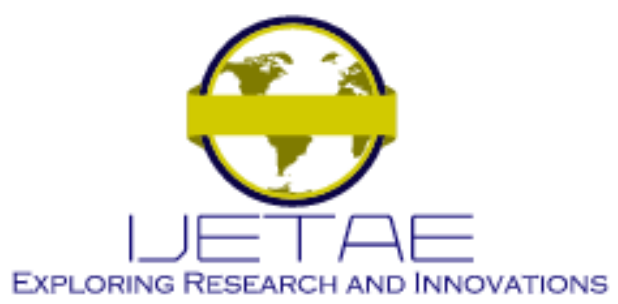

International Journal of Emerging Technology and Advanced Engineering Website: www.ijetae.com (E-ISSN 2250-2459, Scopus Indexed, ISO 9001:2008 Certified Journal, Volume 11, Issue 07, July 2021)

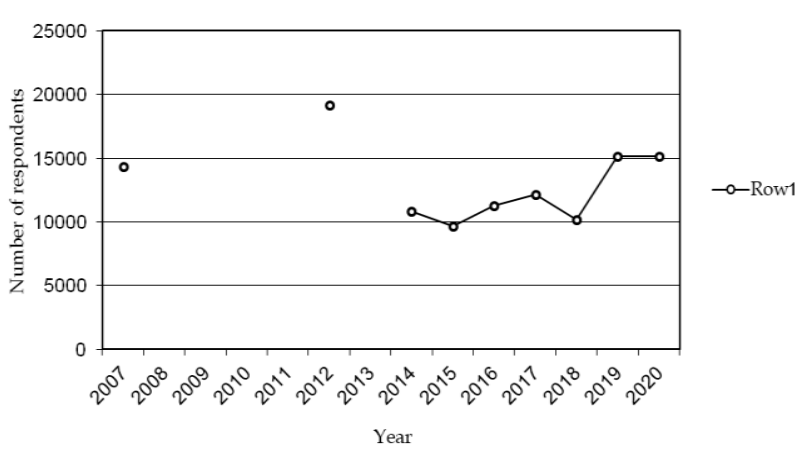

Fig. 10. Public opinion statistics on non-aligned status of Ukraine

The obtained graph shows the trends in public opinion on the non-aligned status of the state since 2007. Let's make the forecast of changes in this opinion by a similar algorithm.

\section{b) the choice of trend (approximating function).}

A comparative analysis of the trends of the statistical series of public opinion on the non-aligned status of Ukraine, conducted according to certain criteria, showed that in this case it is most appropriate to choose a polynomial function of the fourth order (Fig. 11) as an approximating function of the studied process. Unfortunately, less complicated approximate functions of the studied process do not correspond to the strategic objectives of Ukraine's political development.

When calculating trend parameters by a fourth degree polynomial function, the trend equation will have an expression

$y=-13,096 x^{4}+465,39 x^{3}-5467,4 x^{2}+22539 x-3185$.

This trend meets all requirements and is characterized by a high level of reliability of the approximation $\mathrm{R}^{2}=0,8382$.

The calculation of the parameters of the selected trend, the implementation of the point forecast and the assessment of its reliability $\left(\mathrm{R}^{2}=0,8453\right.$ ) was carried out in a similar way. The results of this process are shown in Fig. 12 and Tabl. 4.

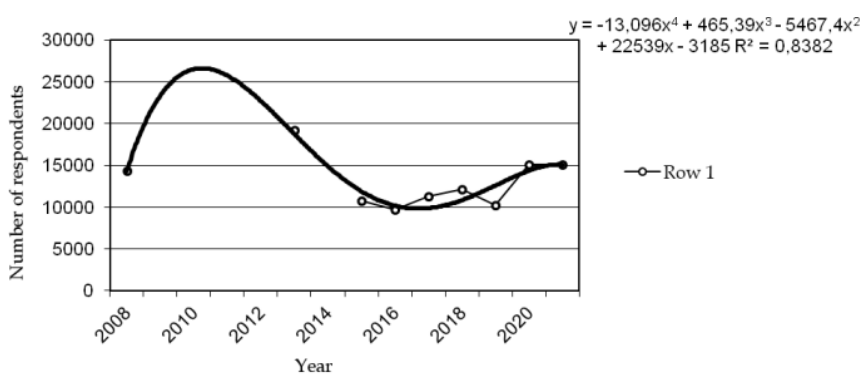

Fig. 11. Approximation of the trend by a fourth degree polynomial function

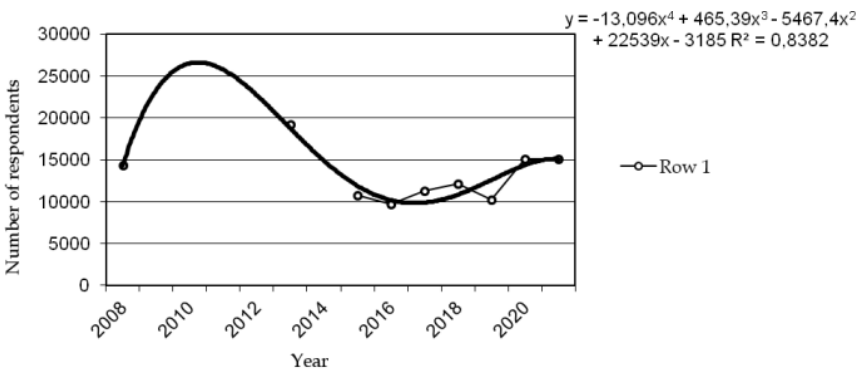

Fig. 12. Prediction of public opinion of the population on the nonaligned status of Ukraine for 2020-2021 when the trend is approximated by a polynomial function of the fourth order

The obtained numerical values of the point forecast of public opinion on the non-aligned status for 2021 and 2022 are shown in Table 4. Similarly, this table shows the increase in the required indicators for 2021-2022.

\section{B. Discussion of the Results of Public Opinion Research in Ukraine}

Summarizing the results of the research on forecasting public opinion in three areas: accession to the EU, NATO and non-aligned status of Ukraine, the following conclusions can be made.

1. Due to a well-founded choice of trends (approximating functions) of public opinion change processes regarding EU accession (second-order polynomial function), NATO (second-order polynomial function) and Ukraine's non-aligned status (fourth-order polynomial function), it was possible to predict desirable general trends. changes in each of them in 2021-2022. 


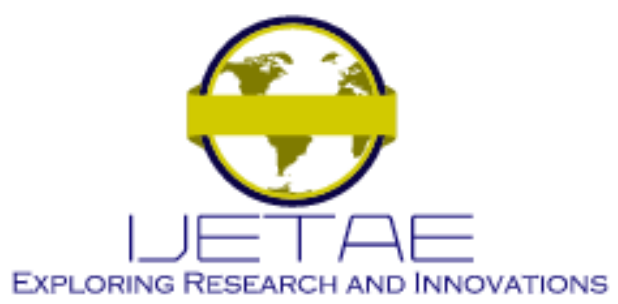

International Journal of Emerging Technology and Advanced Engineering

Website: www.ijetae.com (E-ISSN 2250-2459, Scopus Indexed, ISO 9001:2008 Certified Journal, Volume 11, Issue 07, July 2021)

2. The point forecast data of values of public opinion concerning the certain subjects of interrogation for 2021 2022 have been defined.

The calculations show that with the appropriate organization and implementation of information and psychological impact on certain target audiences, the number of supporters of EU accession will grow and reach a value in 2021 of 22.0 million people. (52.9\%), in 2022 22.7 million people. $(54.6 \%)$. The population that would vote for Ukraine's accession to NATO will also grow and will reach 18.8 million people $(44.7 \%)$ in 2021 and 19.1 million people. $(45.8 \%)$ in 2022 . According to the forecast, the number of supporters of Ukraine's non-aligned status in 2021 will decrease to 14.4 million people $(34.7 \%)$, and in 2022 - to 14.1 million people. (33.8\%).

3. The projected data on the growth (decrease) of the quantitative assessment of the distribution of public opinion on these issues in 2021 and 2022 compared to 2020 have been calculated.

The analysis of these data shows that in order to ensure further positive forecast development of public opinion of the population of Ukraine on accession to the EU and NATO, it is necessary in 2021 and 2022 to increase the number of supporters of society in this direction by 0.5 million people. , $0 \%$ ) in 2021 and 0.7 million people $(1.7 \%)$ in 2022 on EU accession and by 1.7 million people (3.5\%) in 2021 and by 0,2 million people (1.0\%) in 2022 to join NATO. As for the supporters of the non-aligned status of Ukraine, with the appropriate organization of work in the information space, their number will decrease in 2021 by 0.6 million people. (1.7\%) and 0.4 million people $(0.9 \%)$ in 2022 .

4. To achieve these results, the system of strategic communications of the state must provide:

clear definition of a single nationwide strategic narrative and features of its implementation by various state institutions of Ukraine;

creation of mechanisms of systematic, complex influence on specific target audiences by persuasion, reeducation of the public through development and application of high-quality information-psychological and social-patriotic product of European-integration orientation and impossibility of deviation from strategic narrative in carrying out professional activity by various state institutions;

coordinated activities in the information space of all state institutions of Ukraine.

\section{CONCLUSIONS}

The main goal for the system of strategic communications of the Ministry of Defense and the Armed Forces of Ukraine is to achieve a strategic narrative. As noted above, public opinion statistics on support for EU and NATO accession are somewhat declining, so such a narrative for this system should be a change in public opinion to support the country's strategic course.

Thus, the proposed approach to the implementation of the strategic narrative of the state will provide an opportunity to correctly build and implement a system of information security in the military sphere in the form of strategic communications of the Ministry of Defense and the Armed Forces of Ukraine. The analysis provided an opportunity to identify the main tasks for the system of strategic communications and to realize the interests of the state in the form of public support for the strategic course of the state to gain full membership of Ukraine in the EU and NATO.

Further development of this study should be carried out on the basis of modern scientific methods of the theory of social research and the theory of information operations in order to identify time indicators that characterize the distribution of materials of information influences to each target audience. It is especially important to obtain such information from the temporarily occupied territories of Donetsk and Luhansk oblasts, as well as the Autonomous Republic of Crimea. This will make it possible to correctly identify the target audiences, argue the subject of messages and distribution channels of information and psychological influence.

\section{REFERENCES}

[1] Konstytutsiia Ukrainy vid 28.06.1996 № 254k/96-VR iz zminamy № 2680-VIII vid 07.02.2019, VVR, 2019, № 9.

[2] Ukaz prezydenta Ukrainy № 555/2015 24 veresnia 2015 roku "Pro novu redaktsiiu Voiennoi doktryny Ukrainy".

[3] Pro zatverdzhennia Kontseptsii stratehichnykh komunikatsii Ministerstva oborony Ukrainy ta Zbroinykh Syl Ukrainy : Nakaz Ministra oborony Ukrainy vid 22.11.2017 r. №612/2017. URL:http://www.mil.gov.ua.

[4] G. V. Khudov, Features of optimization of two-alternative decisions by joint search and detection of objects. Problemy Upravleniya I Informatiki (Avtomatika), 2003, № 5, pp. 51-59.

[5] H. Khudov, I. Ruban, V. Lysytsya, P. Kuzyk, O. Symkanych, and R. Khudov, The Method for Determination of Bone Marrow Cells in Photographic Images, International Journal of Emerging Trends in Engineering Research, Vol. 8. № 9, 2020, pp. 5681-5687. DOI: https://doi.org/10.30534/ijatcse/2020/131892020. 


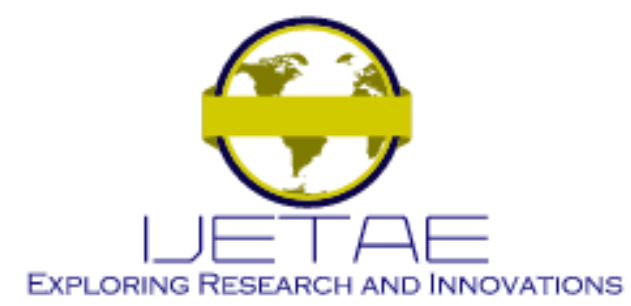

International Journal of Emerging Technology and Advanced Engineering Website: www.ijetae.com (E-ISSN 2250-2459, Scopus Indexed, ISO 9001:2008 Certified Journal, Volume 11, Issue 07, July 2021)

[6] H. Khudov, O. Symkanych, A. Kovalenko, N. Kabus, V. Lysytsya, and R. Khudov, The Comparative Assessment of the Quality of Cytological Drugs Image Processing, International Journal of Advanced Trends in Computer Science and Engineering, Vol. 9. № 5, 2020, pp. 8645-8653. DOI: https://doi.org/10.30534/ijatcse/2020/250952020.

[7] Voitko O.V. Otsiniuvannia efektyvnosti funktsionuvannia systemy stratehichnykh komunikatsii Ministerstva oborony ta Zbroinykh Syl Ukrainy. Naukovyi zhurnal "Systemy upravlinnia, navihatsii ta zviazku”. 2018. - №3(49). - S. 97-99.

[8] Katsalap V.O., Voitko O.V., Cherneha V.M. Metodyka otsinky zahroz informatsiinii bezpetsi Ukrainy u voiennii sferi. Naukovyi zhurnal "Suchasni informatsiini tekhnolohii u sferi bezpeky ta oborony”. 2018. - №1(31). - S.149-154.

[9] Hromadska dumka shchodo vstupu v NATO. [Elektronnyi resurs] Access mode: URL: Rezhym dostupu: https://ukrainenato.mfa.gov.ua/ua/inform-center/ gromadsyka-dumka-shhodovstupu-v-nato.

[10] Yevropeiska intehratsiia u vymiri hromadskoi dumky. [Elektronnyi resurs] - Access mode: URL: Rezhym dostupu: https://dif.org.ua/article/ evropeyska-integratsiya-u-vimirigromadskoi-dumki.

[11] Ukraina na shliakhu do YeS: otsinky, dumky i spodivannia hromadian [Elektronnyi resurs] - Access mode: URL: Rezhym dostupu: http://razumkov.org.ua/statti/ukraina-na-shliakhu-do-yesotsinky-dumky-i-spodivannia-hromadian

[12] Hromadska dumka Ukrainy na 28-mu rotsi nezalezhnosti derzhavy [Elektronnyi resurs] - Access mode: URL: Rezhym dostupu: https://dif.org.ua/article/gromadska-dumka-ukraini-na-28-rotsinezalezhnosti-

derzhavi?fbclid=IwAR0t4aD3U3A9f67v0B_jXFgrFkKVcqZRv0mF MUNi5nvv1bk4NG35_6eJGzw.

[13] Vstupu v YeS khochut use bilshe ukraintsiv - "Reitynh" [Elektronnyi resurs] - Access mode: URL: Rezhym dostupu: https://www.pravda.com.ua/news/2019/06/5/7217188/

[14] Derzhavna sluzhba statystyky [Elektronnyi resurs] - Access mode: URL: Rezhym dostupu: http://www.ukrstat.gov.ua/

[15] V. Lishchenko, H. Khudov, B. Lisogorsky, O. Baranik, D. Holovniak, and O. Serdjuk The MIMO System on Based Existing Mechanical Rotation Radars with Wide Surveillance Area, in 2020 IEEE 40th International Conference on Electronics and Nanotechnology (ELNANO), 2020. P. 625-628. DOI: https://doi.org/10.1109/ELNANO.50318.2020.90887463.

[16] H. Khudov, S. Glukhov, O. Maistrenko, A. Fedorov, A. Andriienko, O. Koplik, The Method of ADS-B Receiver Systems Synchronization Using MLAT Technologies in the Course of Radar Control of Air Environment, International Journal of Emerging Trends in Engineering Research, Vol. 8. № 5, 2020, pp. 1946-1951. DOI: https://doi.org/10.30534/ijeter/2020/78852020.
[17] H. Khudov V. Lishchenko, A. Irkha, and O. Serdjuk, The method of the high accuracy finding 2D coordinates in MIMO-radar based on existing surveillance radars, 2019 International Conference on Information and Telecommunication Technologies and Radio Electronics, UkrMiCo 2019, Odessa, Ukraine, 2019, pp. 1-4, doi: 10.1109/UkrMiCo47782.2019. 9165319.

[18] V. Lishchenko, T. Kalimulin, I. Khizhnyak, and H. Khudov, The method of the organization coordinated work for air surveillance in MIMO radar, Paper presented at the 2018 International Conference on Information and Telecommunication Technologies and Radio Electronics, UkrMiCo, 2018 - Proceeding. DOI: http://doi.org/10.1109/UkrMiCo43733.2018.9047560.

[19] I. Ruban, O. Makoveichuk, V. Khudov, I. Khizhnyak, H. Khudov, I. Yuzova, and Y. Drob. The Method for Selecting the Urban Infrastructure Objects Contours, in Intern. Scient.-Pract. Conf. Problems of Infocommunications. Science and Technology $\begin{array}{llll}\text { (PIC S\&T), 2019, } & \text { 68. }\end{array}$ DOI: https://doi.org/10.1109/infocommst.2018.8632045.

[20] I. Ruban, and H. Khudov, Advances in Spatio-Temporal Segmentation of Visual Data, Chapter 2. Swarm Methods of Image Segmentation. Series Studies in Computational Intelligence (SCI), Vol. 876. - Publisher Springer, Cham, 2020. - P. 53-99. DOI https://doi.org/10.1007/978-3-030-35480-0.

[21] "Stratehichnyi naratyv": do problemy realizatsii sutnisnoi skladovoi stratehichnykh komunikatsii v Ukraini". Analitychna zapyska [Elektronnyi resurs] - Access mode: URL: Rezhym dostupu: https://niss.gov.ua/doslidzhennya/informaciyni-trategii/strategichniynarativ-do-problemi-realizacii-sutnisnoi.

[22] Roselle, Laura \& Miskimmon, Alister \& O'Loughlin, Ben. (2014). Strategic narrative: A new means to understand soft power. Media, War \& Conflict. 7. 70-84. 10.1177/1750635213516696.

[23] Szostek, J. (2017). The Power and Limits of Russia's Strategic Narrative in Ukraine: The Role of Linkage. Perspectives on Politics, 15(2), 379-395. doi:10.1017/S153759271700007X.

[24] Alister Miskimmon, Ben O'Loughlin \& Laura Roselle (2015) Strategic Narratives: a response, Critical Studies on Security, 3:3, 341-344, DOI:10.1080/21624887.2015.1103023

[25] Katsalap V.O. Osoblyvosti spryiniattia ta reahuvannia na otrymanu informatsiiu / Katsalap V.O., Voitko O.V., Cherneha V.M. // Naukovyi zhurnal "Suchasni informatsiini tekhnolohii u sferi bezpeky ta oborony” K.: NUOU. - 2019. - №3(36). - S. 171-174.

[26] Voitko O.V. Systema realizatsii stratehichnykh komunikatsii Ministerstva oborony ta Zbroinykh Syl Ukrainy / Voitko O.V., Solonnikov V.H., Cherneha V.M. // Tezy dopovidei V mizhvidomchoho naukovo-praktychnoho seminaru "Problemy zabezpechennia informatsiinoi bezpeky osobystosti, suspilstva i derzhavy ta shliakhy yikh vyrishennia" 2019 r. - K.: VIKNU, 2019. - S.3-6. 